\title{
THE PARADOXICAL SELF: DUALITY AND AMBIGUITY IN THE WORKS AND LIVES OF OSCAR WILDE AND MORRISSEY ${ }^{1}$
}

\author{
KAROLINA ADAMSKICH
}

\begin{abstract}
Oscar Wilde's and Morrissey's lives seem to be full of contradictions. Their art constitutes a reaction against materialism, traditional lifestyle and social standards, as well as defence of individualism and freedom of thought. So far, their works have been analysed only from a very limited perspective of the tension between aesthetics and ethics. Nevertheless, it is worth mentioning that what prevails in their art is the state of ambivalence and ambiguity in relation to the issues connected with religion and morality, innocence and experience, life and death. This article aims at demonstrating multiplicity of personalities of the artists mentioned and ethical ambivalences of their works. Taken together, Wilde and Morrissey's creative outputs present a clash between different spheres of life, the divided consciousness and the split between body and soul. Thus, the oscillation between opposite standpoints and values excluding each other is not only the result of the artists' personal experience but it may symbolise the paradox and absurdity of the human existence as well.
\end{abstract}

Key words: Oscar Wilde, Morrissey, Christlikeness, the holy fool, performative concept of an artist

Oscar Wilde's life and art seem to be full of contradictions. As his only grandchild Merlin Holland (2004: 3) states, Wilde was "the Anglo-Irishman with Nationalist sympathies, the Protestant with life-long Catholic leanings, the married homo-

\footnotetext{
${ }^{1}$ My previous article (Adamskich 2020) presents Oscar Wilde's attitude to life, to the process of creation and his works' impact on Morrissey's art. The artists' fascination with aestheticism, their defense of humanity and all freedoms, as well as earnestness of their works are investigated in that paper.
} 
sexual, the musician of words and painter of language who confessed to André Gide that writing bored him (...)". Not only did he frequently use paradox in his writings, but he also constituted one. The multiplicity of his personality and art is to be revealed in this article, by means of exploring the tension between religion and morality, innocence and experience, life and death, nature and artifice, aesthetics and ethics.

Similarly, the view that the elements constituting Morrissey's persona as well as his lyrics are deeply paradoxical and contradictory is supported by many of his biographers. Being one of the most legendary contemporary musicians, he distances himself from the world of pop culture and displays his vulnerability and introvertedness. Seemingly inept and awkward, but also witty and brilliant, he is a truly unique artist. Undoubtedly, what makes his works so ambiguous is the fact that Morrissey seems to be torn between aestheticism and ordinariness, using aesthetic imagery but on the other hand claiming that his lyrics are the mouthpiece of the "ordinary folks of the world" (The Smiths, Live on Data Run c. 1984). His "eroticised celibacy" (Hopps 2009: 60), genderlessness and combining melancholy with witticism, in addition, make him similar to Wilde.

\section{Religion and morality}

Wilde's split between rejection of morality and his obsession with religion seems to be a pivotal part of understanding the duality and the paradox of his persona. While much can be found in the literature on the question of Wilde's decadence and preoccupation with sensuality, the fact that his works contain very strong Christian undertones and moral messages has usually been ignored. It can be suggested, however, that both sensual and moralising tendencies are of equal importance in Wilde's works, which is also the case in Morrissey's art.

Wilde's self-detachment from the traditional understanding of morality is presented most expressively in The Picture of Dorian Gray. In the preface to this novel, he argues: "No artist has ethical sympathies" (Wilde 2003: 17). However, this statement should be perceived as Wilde's criticism of didacticism and unimaginativeness in art rather than as an expression of a total disregard for morality. This view is supported by another quotation from the preface, where Wilde (2003: 17) writes: "Vice and virtue are the artist materials for an art". This point shows that, according to Wilde, the artist is free to express every human experience.

The generalisability of much published research on the issue of morality in Wilde's works is problematic and confusing, as it is frequently suggested that Wilde's views on beauty always stay in a strong opposition to ethics. However, although the artist was apparently struggling with doubt in his own life and was spiritually troubled, the Christian message is triumphant in his fairy tales. As argued by Norbert Kohl (2011: 56), they are "redolent of sin and forgiveness, guilt and 
expiation. Thus the situation is detached from the real world and set in an idealised Christian frame of reference". The centre of the stories is constituted by the characters' moral change and revelation which eventually enables them to feel compassion and affection for others. In all the stories, one can find a great amount of empathy towards the poor, the unhappy and those living on the margins of society (McCormack 2004: 102).

Despite such modernist or even postmodernist trends present in Wilde's tales, there is also another reason for them being centered on spirituality and compassion to such an extent. According to Kohl (2011: 55), "[i]n form and structure, Wilde's fairy tales are very much in the tradition of European folk-tales". Owen Dudley Edwards (2003: 15) points out that Wilde's Irish roots cannot be ignored when analysing the stories. He argues that his tales "travel back to a Celtic folk-world dominated by ghosts and God". Thus, it can be hypothesised that the reasons behind their deeply-rooted ethics is both the need to be a mouthpiece of those repressed, and Wilde's cultural background.

The oscillation between aesthetics and ethics - in other words, between the pursuit of individuality, self-indulgence, self-detachment and redemption - is possibly presented to the greatest extent in De Profundis, a letter written to Lord Alfred Douglas during Wilde's imprisonment in Reading Gaol. As Dariusz Pestka (1999: 141) interestingly points out, the letter may be seen as another instance of the introduction of one of the pivotal motifs in Wilde's writings, which is the concept of crime and punishment. Similarly as in The Happy Prince, Wilde comes to the realisation that one cannot live entirely for pleasure, and if one does, it must be balanced by equal amount of suffering. Only through pain it is possible to achieve an ideal communion between the body and mind. Thus, after admitting that he had lived mainly for pleasure, Wilde is concerned with his conflict with the Victorian society and his Christ-like suffering. As Kohl (2011: 284) observes, for Wilde Christ is "the prototype of the suffering artist".

Accordingly, Christ's individualism is praised by Wilde. He sees his own rebellion against Victorian hypocrisy, his trials and incarceration as parallel to Christ's Passion, which may be illustrated by Wilde's words: "The sins of another were being placed to my account. Had I so chosen, I could on either trial have saved myself (...)" (De Profundis, Wilde 2003: 1004). But another passage from De Profundis reveals that Wilde presents himself not only as a martyr but also as a visionary, as he states that he "altered the minds of men and the colours of things" (Wilde 2003: 1017), which is indeed true, as he bridged late Victorian literature with modernism. It can thus be assumed that the artist partially departs from his dandyical image. However, it does not mean abandoning the themes of beauty and art, insofar as, like in all Wilde's works, also in De Profundis aesthetics and ethics interpenetrate.

To illustrate that, it is necessary to look at the ways in which Wilde describes Christ. Interestingly, he chooses very particular adjectives to depict him, such as 
"charming". What he aims to do is to present him primarily as an artist and an individualist, who praises coming to perfection and gaining self-knowledge through suffering and fall. Furthermore, Wilde sees himself as a person similar to Christ, inasmuch as he found new ways of expression. He writes: "The world had always loved the Saint as being the nearest possible approach to the perfection of God. Christ, through some divine instinct in him, seems to have always loved the sinner as being the nearest possible to the perfection of man" (De Profundis, Wilde 2003: 1036). This, like in the case of the tales, can be conceivably perceived as another instance of Wilde's embracing those who fall or do not conform to the rules. Furthermore, Wilde (2003: 1027) assumes that "Christ's place indeed is with the poets" and calls Christ's life "the most wonderful of poems" (2003: 1028). According to Wilde, what is highly romantic about Christ is not only his love and sympathy but also his aim at making people innocent and pure. Wilde (2003: 1035) writes:

He was the first person who ever said to people that they should live flower-like lives. (...) His justice is all poetical justice, exactly what justice should be. The beggar goes to heaven because he had been unhappy. I can't conceive a better reason for him being sent there.

Kohl (2011: 284) observes:

He [Wilde] sees Jesus as a charismatic figure whose life and work, especially the last Stations of the Cross, are like an heroic epic of unheard-of tragic proportions, such as not even Aeschylus or Sophocles, Dante or Shakespeare had ever conceived. The miracles can be attributed quite naturally to the 'charm of his personality'.

As it can be seen, Wildean Christ symbolizes the union between aesthetics and ethics, insofar as he is described not only as an artist and a non-conformist but also as an individual who teaches the value of sympathy and love. Thus, Wilde's posing as a Christ-like figure can be looked as the writer's attempt to find explanation for his suffering. As a result, he sees his fall both as a punishment for living entirely for pleasure and revenge from the side of the hypocritical society. Just like Christ, the leader of individualists, creators and lovers, also Wilde is a victim of society. However, Wilde tries to look at his fall as a crucial element of purification and coming to self-realization. Thus, his incarceration is also his personal victory because, as he states, "[w]here there is Sorrow there is holy ground" (De Profundis, Wilde 2003: 1011). In view of this statement, it is clear that De Profundis is a turning point in Wilde's artistic as well as personal life. Although he unifies his previous ideas on art with the figure of Christ, he also seems to abandon some of his views:

And delightful as cynicism is from its intellectual side, (...) it never can be more than the perfect philosophy for a man who has no soul. It has its social value, and to an artist all modes of expression are interesting, but in itself it is a poor affair, for to the true cynic nothing is ever revealed (Wilde 2003: 1049). 
Morrissey has criticised the Catholic Church on some occasions, claiming for instance: "I could never make the connection between Christian and Catholic. I always imagined that Christ would look down upon the Catholic Church and totally disassociate himself from it" (as cited in: Devereux 2010: 68). However, Morrissey's lyrics are full of religious allusions and Christian imagery.

Similarly to Wilde, Morrissey has often posed as a martyr and has presented himself as a religious figure. It has resulted partly from his reluctance to conform to the rules established by the show-business and also from his asceticism. His often proclaimed celibacy and the avoidance of drugs and alcohol has been frequently followed by statements made by the artist. He maintained, for instance, that "he lead[s] somewhat of a religious lifestyle" (Hopps 2009: 229). On another occasion, Morrissey went even further and stated: "I live a life that befits a priest virtually... I live a saintly life" (Hopps 2009: 229).

However, religious allusions can be also found in Morrissey's lyrics. In some of them, they are overtly present in the form of "Catholic colloquial expressions" (Devereux 2010: 69), such as "Oh God", "Lord knows", or "Heaven knows". In the rest of them, however, religious imagery is introduced in more subtle ways.

To begin with, a great part of Morrissey's lyrics is replete with the paraphrases of the Bible. By way of illustration, the first line of These Things Take Time (The Smiths 1984, Hatful Of Hollow) seems to be borrowed from The Battle Hymn of the Republic, which is a paraphrase of the biblical verse from Exodus 34: 29-35, as the speaking persona says: "Mine eyes have seen the glory of the sacred Wunderkind". In the biblical version, in comparison, the first passage runs as follows: "Mine eyes have seen the glory of the coming Lord" (Devereux 2010: 70). However, the biblical imagery is used by Morrissey even more surprisingly in the song Suffer Little Children (The Smiths 1984, The Smiths). The ambiguity of the title results from the fact that the verb to suffer used to have the second meaning, which was 'to allow'. Thus, when Christ speaks of "suffering", he means 'allowance' (Devereux 2010: 70). The Smiths' song, however, tells the story of the murder of the children. Hence, the title of the song may be interpreted as a request to allow children to come, possibly to the murderers, or as a perverse need to see the children suffer.

Morrissey has been also frequently presented as a preacher, as the behaviour of his fans can be seen as "quasi-religious" (Hopps 2009: 181). This view is supported by John Harris (as cited in Hoppes2009: 229): "His [Morrissey's] disciples, clad in a uniform usually acquired from charity shops, would dance to The Smiths' music using steps that amounted to cartoon gestures of self-pity: hands placed on the heart, eyes cast skywards in the manner of the crucified Christ". This quotation bears resemblance to the words of Wilde, who wrote about Christ that "[his] great achievement was that he made himself as much loved after his death as he had been during his lifetime" (De Profundis, Wilde 2003: 1029). Morrissey, similarly, unlike many other artists, has already become "deified" throughout his life. 
As it can be seen, both in the works of Wilde and Morrissey there is a tension between aesthetics and ethics. In Wilde's case it can be perceived as being torn between sensuality and the obsession with the Catholic Church, which was apparently romantically idealised by the artist. In addition, instead of adopting the hypocritical rules shared by a great part of the Victorian society, he presented himself in his works as a deeply sympathetic artist, full of compassion and tolerance for other people's weaknesses. Furthermore, De Profundis can be seen as Wilde's attempt to recreate himself in spiritual terms. In Morrissey's case, on the other hand, the split between aesthetics and morality is present rather by means of a clash between disappointment, doubt and the artist's religious background. However, it is deeply symbolical that even the connection between Wilde and Morrissey was depicted by the singer by means of religious imagery: "As I get older, the adoration [of Wilde] increases. I'm never without him. It's almost biblical. It's like carrying your rosary around with you" (Hopps 2009: 74).

\section{Innocence and experience}

The term innocence refers to three main meanings (Hornby 1987: 439). First of all, it encompasses the state of not being guilty. It is also generally understood to mean 'knowing nothing of evil or wrong' and resembling a state of mind of a newborn baby. The third meaning, in addition, is 'being foolishly simple' and extremely naïve. The word experience, on the contrary, has come to be used to refer to the 'process of gaining knowledge or skill by doing and seeing things" or "event that affects one in some way', be it a beneficial or devastating act (Hornby 1987: 299). As it is to be presented in this paper, the concepts of innocence and experience are depicted in the works of Oscar Wilde and Morrissey in all possible meanings of these terms.

\subsection{From the stage of ignorance to initiation}

Coming from the state of unawareness and ignorance to self-realization is one of the recurrent motifs in Wilde's fairy tales."Initiation rites", as James Campbell (2015: 31) calls them, are disclosed in almost all the stories, from The Happy Prince and The Selfish Giant to The Star Child. In general, the plot of the tales presents two stages of the characters' lives and their reformation, through which it is possible to achieve the state of "blissful self-awareness" (Pestka 1999: 31). Pestka (1999: 30) states:

(...) the initial stage of the story's development presents the character's substantial imperfection manifested in their lack of proper understanding of their own or environment's nature. Their ignorance effects in the deficiency of affection for others. At this 
stage, two solutions are offered: the characters are either capable of overcoming the flaw of their personality or remain unregenerate.

Surprisingly, unlike fairy tales by other writers, in Wilde's stories there are no tasks to be completed, nor there is divine intervention. As Kohl (2011: 55-56) states, "[c]hanges of attitude or situation are not gradual, but, in nearly all case, sudden and complete, often through the intervention of some supernatural agent. There are miraculous transformations rather than psychological developments". The character's initiation is strictly a mental or emotional one, for they become aware of misery and sensitive to suffering. By way of illustration, in The Happy Prince, the main character lives for pleasure, sensations and beauty. It is only after his death that his statue towers above the city and he finally realises that others live in pain and poverty. Exposed to other people's misery, he sacrifices himself and "[undergoes] moral purification leading to selfless conduct" (Pestka 1999: 31). In his self-sacrifice, he resembles Christ, which adds purely religious undertones to the tale - a characteristic visible in a great part of both Wilde's and Morrissey's writing, as it is to be explored later. Also in The Selfish Giant the main character undergoes a moral change, from the lack of affection to the ability to feel compassion and love. Again, the process of initiation proves beneficial and, as a consequence, it enables the Giant to gain salvation and become unified with Christ. While in The Happy Prince Christian imagery is covert, in The Selfish Giant it becomes explicit:

Downstairs ran the Giantin a great joy, and out into the garden. He hastened across the grass, and came near to the child. And when he came quite close his face grew red with anger, and he said, 'Who hath dared to wound thee?' For on the palms of the child's hands were the prints of two nails, and the prints of two nails were on the little feet. 'Who hath dared to wound thee?' cried the Giant; 'tell me, that I may take my big sword and slay him.' 'Nay!' answered the child: 'but these are the wounds of Love'. 'Who art thou?' said the Giant, and a strange awe fell on him, and he knelt before the little child. And the child smiled on the Giant, and said to him, 'You let me play once in your garden, to-day you shall come with me to my garden, which is Paradise' (Wilde 2003: 285).

As Kohl (2011: 61) points out, Wilde "remains true to conventional morality in his later works, with evil being punished and good rewarded (...)". As it can be observed, the crucial part of initiation is remorse, which eventually leads to purification.

Wilde's life bears astonishing resemblance to the plot of his fairy tales. Preoccupied with beauty, sensuality and the pleasure principle, he seemed to have fully embraced state of self-awareness and initiation in prison. The quotation from $D e$ Profundis shows this point clearly, as Wilde (2003: 1037) writes: "Of course the sinner must repent. But why? Simply because otherwise he would be unable to realise what he had done. The moment of repentance is the moment of initiation. More than that. It is the means by which one alters one's past'. He seems to be convicted that one may achieve self-realization and happiness only through pain: 
Sorrow, then, and all that it teaches one, is my new world. I used to live entirely for pleasure. I shunned sorrow and suffering of every kind. I hated both. I resolved to ignore them, that is to say, as modes of imperfection (...) There is not a single wretched man in this wretched place along with me who does not stand in symbolic relations to the very secret of life. For the secret of life is suffering (Wilde 2003: 1023).

What is more, behind pain and suffering lies not only self-realization but also love, both in the case of the tales and Wilde's personal life - as he writes in De Profundis (Wilde 2003: 1025): "Now it seems to me that Love of some kind is the only possible explanation of the extraordinary amount of suffering that there is in the world. (...) Pleasure for the beautiful body, but Pain for the beautiful Soul".

Despite the fact that innocence and experience are recurrent motifs in Morrissey's works and, just like in Wilde's case, initiation is often described by means of Christian imagery, in Morrissey's lyrics the state of self-awareness is connected with corruption rather than redemption. Unlike Wilde, Morrissey describes primarily sexual awakening, not moral or religious one. What may seem particularly shocking and unusual is the fact that most songs concerned with the theme of the innocence loss present child-centered lyrics and depict innocence-abusers. It may be exemplified by the tracks such as Reel Around The Fountain (1984, The Smiths) or The Hand That Rocks The Cradle (1984, The Smiths), which include pedophiliac connotations and have been often perceived as perverse.

The most disturbing part of Reel Around The Fountain, a "tale of innocence and experience" (Hopps 2009: 150), is probably its beginning with the sentence: "It's time the tale were told of how you took a child and you made him old". Beginning like a fairy tale, it apparently tells the story of desire and sexual yearning. Another case of controversial depiction of the loss of innocence is presented in The Hand That Rocks The Cradle. Introducing one fixed interpretation of the lyrics would be problematic, as this song, just like other Morrissey's works, is enigmatic and ambiguous. It is a monologue of a man who is talking to a three-year-old boy and who is expressing his care and affection for him. The lyrical "I" says: "Please don't cry for the ghosts and the storm outside will not invade this sacred shrine, nor infiltrate your mind. My life down I shall lie if the bogey-man should try to play tricks on your sacred mind, to tease, torment and tantalize". These words remind one of the passages from Wilde's The Selfish Giant, where the Giant wants to protect his beloved boy from any harm. Innocence is depicted as "sacred" and the child itself as pure and vulnerable. However, the last part of the song reveals "predatory undertow" (Whiteley 2010: 109), as the man says:

I just looked into his wondrous eyes and said: never never never again. And all too soon I did return just like a moth to a flame. (...) Together we lie, together we pray. (...) Climb up on my knee, sonny boy. Although you're only three, sonny boy, you're mine. And your mother, she just never knew (The Hand That Rocks The Cradle, 1984, The Smiths). 
In a way, the boy is perceived as a possession, not an independent human being, but again, just like in case of Reel Around The Fountain, the bounds between two people are enigmatic, inasmuch as they are based both on obsession and love. Yet another example of initiation viewed as corruption is depicted in Miserable Lie (1984, The Smiths), where Morrissey borrows the phrase "flower-like life" from Wilde: "You have destroyed my flower-like life, not once - twice. You have corrupted my innocent mind, not once - twice. I know 'the windswept mystical air', it means: I'd like to see your underwear". Again, sexual awakening is looked upon almost like a criminal act, with a sexual intercourse totally separated from love and treated like an abuse.

As the aforementioned examples show, innocence in the works of Wilde and Morrissey is associated with the state of ignorance. However, the results of initiation seem to be reversed in case of both artists. For Wilde, the state of ignorance is equal with not knowing oneself and being remote from the true secret of life and God. Thus, experience proves to be blissful, as it enables to be in tune with oneself. In Morrissey's lyrics, on the contrary, experience often turns out to be traumatic.

\subsection{The loss of moral innocence}

The other meaning of the word innocence is 'not being guilty of any crime'. Thus, in the light of this definition, "experience" would be connected with evil and sin. This concept is present in The Picture of Dorian Gray. As Pestka states (1999: 45):

In its construction following the Garden of Eden or Faust myths, The Picture of Dorian Gray includes the characteristic motifs of temptation, fall, retribution, and hypothetical redemption. In the initial scene disclosing the Edenic beauty of Basil's studio with the adjacent garden, both Dorian and his portrait epitomize youth and pastoral innocence, whereas the painter, in whose company the former has spent his time recently, and who is the creator of the latter, stands for a moral force. At this point, however, Dorian is exposed for the first time to pernicious influence of Lord Henry, whose "seductive picture of the fruits awaiting youth and beauty is the immediate cause of Dorian's looking at his own likeness with new eyes".

Thus, though at first afraid of the poisonous words of Henry Wotton, Dorian quickly undergoes transformation and decides to live according to "New Hedonism". "The new Hedonism (...) is to be an ethical alternative to puritanism. It is based on the Epicurean and Cyrenaic schools of philosophy, in which pleasure (i்oví) is the only good in life" (Kohl 2011: 158). Dorians's initiation is thus opposite to the presented in Wilde's fairy tales. In the fairy tales, experience leads directly to becoming sensitive to misery and loving, whereas in The Picture of Dorian Gray adopting Lord Henry's idea of self-development excludes other people's emotions and morality. What at first seems to be a mere living in accordance to aestheti- 
cism ceases to be innocent. In his work, Pestka (1999: 49) writes: "Dorian's perverse flirtation with his own moral decline now is no longer possible for him to aesthicise evil". Hence, one can observe a link between the poisonous influence of Lord Henry on Dorian and the depiction of abuse present in Morrissey's lyrics, as the corruption of the character's mind results in the loss of moral innocence.

\subsection{Holy fools}

As it has been mentioned, the term innocence may be used to describe the state of being 'foolishly simple' as well. Such a concept seems to have been fully embraced both by Wilde and Morrissey, being yet another instance of using Christian imagery and biblical language to describe the state of innocence.

In De Profundis Wilde (2003: 981) writes to Douglas that "the fool in the eyes of the gods and the fool in the eyes of man are very different". These words supposedly have their roots in the New Testament, where the Apostle Paul says to the Corinthians: "We are fools for Christ's sake, but ye are wise in Christ; we are weak, but ye are strong; ye are honourable, but we are despised" (1 Corinthians 4: 10). As can be concluded from this quotation and from Christian preaching in general, being a holy fool refers to challenging societal norms and conventions and denouncing hypocrisy to imitate Christ. These issues were comprehensively addressed by Cezary Wodziński in his work (Wodziński 2000). Furthermore, Peter Phan (2001: 730) states that "the wisdom of the holy fool is characterized by irony, fantasy and knowledgeilluminated-by-love", which may resonate with Wilde's and Morrissey's persona.

Wilde, who in De Profundis compared himself to Christ several times, writes about him that "He took children as the type of what people should try to become" (Wilde 2003: 1035) and that "when one comes in contact with the soul it makes one simple as a child, as Christ said one should be" (Wilde 2003: 1030). During his imprisonment, Wilde's obsession with Catholicism seemed to become even stronger, hence he describes Christ as a Supreme artist and individualist. Thus, imitating Christ and the preoccupation with being innocent in the eyes of God can be seen as most important in the last phase of Wilde's career. A strong link may be observed between this and the words of Phan (2001: 737):

The paradoxical idea that the fool may be wise (...) was as old as humanity itself, since it is a common experience that untutored and simple-minded, including children, can penetrate to profounder truths than the lettered and the learned. Jesus alluded to this fact when he gave thanks and praise to God his Father for having hidden from the learned and the clever what he has revealed to the merest children.

But one of the others characteristics of a holy fool is indifference to social conventions and living in society, yet without sharing rules of behaviour of others and acting in a provocative way (Phan 2001: 743). Wilde's writing was provocative, full 
of irony and partially aimed at denouncing hypocrisy and, in the later phase of his writing, at "unit[ing] oneself with the divine or reach[ing] enlightenment" (Phan 2001: 742). Moreover, according to Hopps (2009: 246), leading an ascetic life is crucial in relation to a holy fool. It resonates with Wilde's persona, as he writes in De Profundis (Wilde 2003: 1019): "I would gladly and readily beg my bread from door to door. If I got nothing from the house of the rich, I would get something at the house of the poor". In the same way, Wilde praises St. Francis of Asisi:

God had given him at his birth the soul of a poet, as he himself when quite young had in mystical marriage taken poverty as his bride: and with the soul of a poet and the body of a beggar he found the way to perfection not difficult. He understood Christ, and so became like him (De Profundis, Wilde 2003: 1037).

According to Hopps (2009: 247): "In stepping outside society's norms, and in attempting to expose the folly of the world's way by being embarrassingly otherwise, Morrissey resembles a traditional and subversive but not largely forgotten figure: the holy fool". This view seems to be supported by several other sources, where Morrissey has been frequently described as an "idiot":

Morrissey is needed, not as an ombudsman, or a figure of the Eighties but as a horrified figure against the Eighties who has turned his back on the march of pop time as the last keeper of the sanctuary of self-pity, apartness, exile... And Viva Hate is another great album by our last star, our last idiot (Hopps 2009: 246).

Obviously, being a celebrity, Morrissey cannot fully epitomize the term "holy fool" but there are certain characteristics of such a figure that he possesses. First of all, Morrissey's "art of weakness", as Hopps (2009: 13) puts it, reminds one of St. Paul's statement: "my strength is made perfect in weakness" (2 Corinthians 12: 9). His celibacy and asceticism, not settling in one place, playing a fool, shocking and making people uncomfortable by his own embarrassment, as well as making provoking statements also bring him closer to this category.

Accordingly, Morrissey also argued: "There's something so positive about unemployment. You don't get trapped into materialism, you won't buy things you don't really want" (Sounds, June 4, 1983). Apart from this, his solidarity with outcasts suggests that at least some of Morrissey's behaviour "has a religious model behind it" (Hopps 2009: 246).

\section{Life and death}

Even the very beginning of The Smiths is metaphorically embedded into the themes of life and death, as Morrissey ceased to use the names "Steven Patrick" and, in a way, a new person was born. A change of name or rather eradicating a part of it 
can be seen as a symbolic act, a first step into the creation of a "mythic personality" (Hopps 2009: 2), enigma and a living symbol.

\subsection{Life which has not begun and an unlived life}

The theme of unlived life is present in a great part of Wilde's work. As it has been mentioned, one of the reasons behind the fascination with the subject may be the artist's preoccupation with the correlation between art and life.

In The Picture of Dorian Gray, by way of illustration, Sibyl Vane is defined by her acting to such an extent that without it she is powerless and less real than the characters that she is playing. Thus, both her life and death are presented as such:

The girl never really lived, and so she has never really died. (...) Mourn of Ophelia? If you like. Put ashes on your head because Cordelia was strangled. Cry out against Heaven because the daughter of Brabantio died. But don't waste your tears over Sibyl Vane. She was less real than they are (Wilde 2003: 82).

The theme of the life which has not begun is present in Wilde's fairy tales as well. It is the process of gaining experience which is the beginning of the characters' true existence. In this context, the ability to love an feel compassion is a metaphorical death of the previous selfish imperfect self.

Morrissey's fascination with the themes of being placed in-between life and death and an unlived life has been visible throughout his whole career. In one of the interviews, he argued: "I just wanted to be me, which is somewhere between this world and the next world" (Melody Maker, September 27, 1986). The value of this statement suggests that a strong link may exist between Morrissey's very persona and his preoccupation with such themes.

The oscillation between this and another world is a recurrent theme in Morrissey's works. Along with writing from the perspective of a ghost, he addresses yet another problem - an unlived life and the life which has not yet begun. One of the songs which encompasses this issue is Suffer Little Children (1984, The Smiths), where the future victims are placed in between life and death, with the perspective of losing their lives stuck at the back of their minds. One of the children addresses the murderer: "Over the moor, take me to the moor. Dig a shallow grave and I'll lay me down". Such a depiction of death-in-life is especially haunting because of the fact the burial of the victims is premature.

Morrissey, however, wrote not only about a literal death, an example being the songs such as Half A Person (1987, The World Won't Listen), How Soon Is Now (1985, Meat Is Murder), Shoplifters Of The World Unite (1987, Louder Than Bombs) or Rubber Ring (1987, Louder Than Bombs). In most of them, the speaking persona is barely existing because of being weak, fragile and vulnerable, hence the 
use of the phrases such as "flower-like life". An illustration of a "ghostly state" (Hopps 2009: 282) is another quotation, where lyrical "I" states: "I am a ghost and as far as I know I haven't even died" (I'll Never Be Anybody's Hero Now, 2006, Ringleader Of The Tormentors). On various occasions, however, a speaking persona shows willingness to alter the state of being "outside" life, but such attempts are always fruitless. In There Is A Light That Never Goes Out (1986, The Queen Is Dead), for instance, there are words: “Take me anywhere, I don't care, I don't care. And in the darkened underpass I thought 'Oh God, my chance has come at last' (but then a strange fear gripped me and I just couldn't ask)". In another song, Shoplifters Of The World Unite (1987, Louder Than Bombs), the state of hopelessness is articulated in the following way: "Tried living in the real world instead of a shell. But before I began... I was bored before I even began”. It can thus be suggested that reality has not much to offer and isolation comes as a better solution.

Lastly, in-between-ness and death-in-life are presented in an ironic and humorous way in What She Said (1985, Meat Is Murder), where a young woman states: "How come someone hasn't noticed that I'm dead and decided to bury me? God knows I'm ready!". But the theme of fragile existence, depression and "the passing of time [which] leads empty lives waiting to be filled" (Rubber Ring, 1987, Louder Than Bombs) brings about another serious issue, which is to be explored in the following chapter, mainly suicide.

\subsection{Self-destruction}

One of the central themes in Wilde's works is self-destruction, which is presented rather as a long process than one action. It is depicted most expressively in The Picture of Dorian Gray. The main character's self-destruction begins when the man decides to adopt a hedonistic approach and dedicates his life to artifice. As a consequence, Dorian's recognition of his beauty begins the process of the split between his body and soul and a fall which results from it. This view is supported by McCormack (2004: 114) who states that "The Picture of Dorian Gray is (...) the record of a long and lovely suicide". He also concludes that substituting art for life resulted in the fact that Dorian ceased to be a real person and gained the quality of an object: "From the moment he speaks his desire, Dorian himself becomes an artifact, neither alive, nor dead" (McCormack 2004: 113).

Interestingly, one can observe a parallel between the plot of Wilde's novel and his own life. He also became in a way a work of art, inasmuch as his art and life fluctuated. Thus, in the case of Dorian Gray the preoccupation with aesthetics and abandoning ethics led to his fall, just like in Wilde's case the novel itself proved to be fatal for its author, as "it was used as the evidence of his "immorality" in the three trials which ended in his imprisonment" (McCormack 2004: 114). 
Throughout his career, Morrissey has referred to the theme of self-destruction in a variety of ways, usually by means of writing about suicide. However, suicide in Morrissey's lyrics has never been presented explicitly, but rather in a peaceful, yet haunting way. The illustration of such a depiction may be The Smiths' song Asleep (1987, The World Won't Listen), in which falling asleep is a metaphor for death. Presenting this issue in such a way may have its roots in the fact that the artist has always taken a particular interest in the theme of being inept and lethargic, which is close to the imagery of sleeping. What is more, Kieran Cashell points out that the link between suicide and sleeping was made in Shakespeare's Hamlet, where one can find the words: "To die, to sleep" (Cashell 2010: 88). In Asleep, suicide is viewed as an escape from weariness and loneliness, as it can be shown by the following part of the song: "Sing me to sleep. I'm tired and I want to go to bed. (...) Sing me to sleep, I don't want to wake up on my own anymore. Sing to me (...)". Interestingly, while for many authors death is the ultimate end, Morrissey seems to adopt a more Christian view, with the belief in the existence of the afterlife: "There is another world. There is a better world. Well, there must be". This line, however, gives the song an ambiguous tone, as suicide is rather an act committed in hope of being the final end, not a new beginning. Thus, it is difficult to tell precisely whether the statement "Well, there must be" is full of hope and should be comforting, or if it meant to create the mood of resignation, as it implied that one is bound to exist in one or another form.

\subsection{Belonging and not-belonging}

One of the reasons behind Wilde's art and his very persona being so unusual is probably his sense of non-belonging. Constituting paradoxes, he was torn between Ireland and England, the family life and homosexual desires, as well as belonging to the aristocracy and yet despising its values. Such a dissonance was mirrored in his society comedies (eg. The Importance of Being Earnest, Lady Windermere's Fan, A Woman of No Importance, An Ideal Husband), in which he mocked the Victorian upper class, and the principle of non-attachment.

The split between the sense of belonging and non-belonging in Wilde's society comedies can be seen in the fact that, despite some of the characteristics and rules representing by the Victorian aristocracy, he also conformed to their tastes, insofar as he used the devices typical for the nineteenth century plays (Pestka 1999: 89). Furthermore, Pestka (1999: 89) suggests that Wilde "(...) can be considered a counterpart of his dandies suspended between conformity to the social rules and playing with them". Thus, melodrama and sentimentality are balanced by wit and sarcasm.

The contrast between professing certain ideas, yet not joining in is seen also in The Picture of Dorian Gray, where Lord Henry postulates new Hedonism, but does 
not participate in others' actions and affairs. Again Pestka (1999: 56) claims: "The image of the dandy alienated from the social reality was cherished by Byron and Disraeli in England. Such is the genesis of the Wildean dandy whose predominant feature is the principle of non-attachment". Thus, it can conceivably be presumed that the sense of non-belonging and non-attachment present in Wilde's art is both a consequence of his paradoxical persona and the features of a dandy.

Non-belonging is a crucial issue in Morrissey's writing as well. The reasons for his lyrics being filled with a sense of exile and foreignness are numerous and thus have been articulated in abundant ways.

One of the possible reasons behind adopting such a pattern in his writing is Morrissey's Anglo-Irish identity. Born and raised in Manchester, he spent his entire childhood and teenage years with his Irish parents and the rest of his large extended family, which had left Dublin and settled in England (Brown 2009: 49). This situation resulted in ambiguity, the evidence of which is for instance the title one of Morrissey's solo songs, Irish Blood, English Heart (Morrissey, 2004, You Are The Quarry). In the interview for Irish Times from 1999 (Campbell S. 2010: 57) the artist said: "It was always odd when I was described as being 'extremely English' because other people would tell me that I looked Irish, I sounded Irish and other telltale signs". There are several other cases where Morrissey stressed his inbetween-ness. For instance in Still Ill (1984, The Smiths), there is a passage: "I decree todaythat life is simply taking and not giving. England is mine - it owes me a living". However, Morrissey would on some occasions replace the world "England" with "Ireland", especially when touring in his motherland (Campbell S. 2010: 44). Morrissey also stressed the fact of being extremely conscious about his Irish ethnicity and, therefore, feeling a strong sense of non-belonging to the Manchester community (Campbell S. 2010: 45). It is possible, therefore, that the theme of leaving and being away from home which is present in a great part of Morrissey's lyrics is a metaphor for being unable to fully assimilate and the absence of the safety haven. It is apparent in the tracks such as Back To The Old House (1987, Louder Than Bombs), Everyday Is Like Sunday (1988, Viva Hate) and There Is A Light That Never Goes Out (1986, The Queen Is Dead). In the first of the aforementioned songs, the speaking persona is apparently torn between the revulsion and temptation to the idea of returning home, a country or a person whom he left behind. Although in the first line there is a statement: "I would rather not go back to the old house. There is too much bad memories", in the last part of the song the speaking "I" expresses a contradictory need: "I would love to go back to the old house but I never will". Interestingly, the same theme of not being able to return is present in a similar form in one of The Smiths' most popular tracks, There Is A Light That Never Goes Out (1986, The Queen Is Dead): “Oh please don't drop me home/ because it's not my home, it's their/ home and I'm welcome no more". This song, more than a previous one, evokes also a sense of homelessness. But whereas in There Is A Light...the 
speaking persona can find solace in the company of a lover, a far more pessimistic mood is created in Everyday Is Like Sunday. In the song, the usual holiday greetings from a postcard are humorously and ironically reversed, as if the idea of a holiday resort in Britain was ridiculous because of the British seaside towns' miserableness. This, again, connects the singer's sense of non-belonging and loneliness with the fact that he seems to perceive England as foreign, ridiculous and hostile.

In Morrissey's lyrics, however, the sense of having no roots results not only from the problem of ambiguous national identity but also from not belonging to any person. As it was mentioned before, in several songs and interviews Morrissey expressed a kind of passivity in connection to relationships and the feeling of spending life in isolation. In I Am Hated For Loving (1994, Vauxhall And I), by way of illustration, he says: "I still don't belong to anyone - I am mine". Interestingly, the words "I am mine" suggest pride and coming to terms with one's loneliness and non-belonging rather than misery. In the next verse, however, Morrissey sings: "I am falling with no one to catch me", which seems to create a totally different mood of frustration and disappointment.

In conclusion, it can be stated that the oscillation between opposite standpoints and values excluding each other result not only from the artists' personal experience but they may symbolise the paradox and absurdity of the human existence as well. Thus, taken together, Wilde and Morrissey's creative outputs present a clash between different spheres of life, the divided consciousness and the split between body and soul.

\section{References}

Adamskich, K. 2020. “Oscillate Wildly: Morrissey's art and persona as a continuation of Oscar Wilde's artistic legacy”. Scripta Neophilologica Posnaniensia 20. 249-261.

Brown, L. 2009. meetings with Morrissey. London: Omnibus Press.

Campbell, J. 2015. Oscar Wilde, Wilfred Owen and male desire: begotten, not made. Basingstoke/New York: Palgrave Macmillan.

Campbell, S. 2010. "Irish blood, English heart: ambivalence, unease and The Smiths". In: Campbell, S. and C. Coulter (eds). Why pamper life's complexities? Essays on The Smiths. Manchester/New York: Manchester University Press. 43-64.

Cashell, K. 2010. "Sing me to sleep: suicide, philosophy and The Smiths". In: Campbell, S. and C. Coulter (eds). Why pamper life's complexities? Essays on The Smiths. Manchester/New York: Manchester University Press. 81-103.

Devereux, E. 2010. "Heaven knows we'll soon be dust: Catholicism and devotion in The Smiths". In: Campbell, S. and C. Coulter (eds). Why pamper life's complexities? Essays on The Smiths. Manchester/New York: Manchester University Press. 65-80.

Edwards, O.D.2003. "Introduction: the stories of Oscar Wilde". In: Wilde, O. The complete works of Oscar Wilde. London: HarperCollins Publishers.

Holland, M. 2004. "Biography and the art of lying". In: Raby, P. (ed.). The Cambridge companion to Oscar Wilde. Cambridge: Cambridge University Press. 3-17. 
Hornby, A.S. 1987. Oxford advanced learner's dictionary of current English. Oxford/New York: Oxford University Press.

Hopps, G. 2009. Morrissey: the pageant of his bleeding heart. London: Continuum.

Kohl, N. 2011. Oscar Wilde: the works of a conformist rebel. (Translated from German by D. H. Wilson). Cambridge/New York/Port Chester/Melbourne/Sydney: Cambridge University Press.

McCormack, J. 2004. "Wilde's fiction(s)". In: Raby, P. (ed.). The Cambridge companion to Oscar Wilde. Cambridge: Cambridge University Press. 143-160.

Pestka, D. 1999. Oscar Wilde: between aestheticism and anticipation of modernism. Toruń: Wydawnictwo Uniwersytetu Mikołaja Kopernika.

Phan, P. 2001. "The wisdom of holy fools in postmodernism". Theological Studies 62. 730-752.

Powell, K. 2011. Acting Wilde: Victorian sexuality, theatre, and Oscar Wilde. Cambridge: Cambridge University Press.

Raby, P. (ed.). 2004. The Cambridge companion to Oscar Wilde. Cambridge: Cambridge University Press.

The Smiths. Live on Data Run c. 1984 (http://www.youtube.com/watch?v=rolR4Ou8t8w). Web. 15.06.2019.

Whiteley, S. 2010. "A boy in the bush: childhood, sexuality and The Smiths". In: Campbell, S. and C. Coulter (eds). Why pamper life's complexities? Essays on The Smiths. Manchester/New York: Manchester University Press. 104-120.

Wilde, O. 2003. The complete works of Oscar Wilde. London: HarperCollins Publishers.

Wodziński, C. 2000. Święty Idiota. Projekt antropologii apofatycznej. Gdańsk: Słowo/obraz terytoria.

\section{Song lyrics}

Morrissey. "Miserable Lie". Na płycie: The Smiths. The Smiths. Rough Trade Records, 1984.

Morrissey. "Reel Around The Fountain". Na płycie: The Smiths. The Smiths. Rough Trade Records, 1984.

Morrissey. "Still Ill”. Na płycie: The Smiths. The Smiths. Rough Trade Records, 1984.

Morrissey. "Suffer Little Children". Na płycie: The Smiths. The Smiths. Rough Trade Records, 1984.

Morrissey. "The Hand That Rocks The Cradle". Na płycie: The Smiths. The Smiths. Rough Trade Records, 1984.

Morrissey. "These Things Take Time”. Na płycie: The Smiths. Hatful Of Hollow. Rough Trade Records, 1984.

Morrissey. "How Soon Is Now". Na płycie: The Smiths. Meat Is Murder. Rough Trade Records, 1985.

Morrissey. "What She Said". Na płycie: The Smiths. Meat Is Murder. Rough Trade Records, 1985.

Morrissey. "There Is A Light That Never Goes Out". Na płycie: The Smiths. The Queen Is Dead. Rough Trade Records, 1986.

Morrissey. Back “To The Old House”. Na płycie: The Smiths. Louder Than Bombs. Sire Records, 1987.

Morrissey. "Rubber Ring". Na płycie: The Smiths. Louder Than Bombs. Sire Records, 1987.

Morrissey. "Shoplifters Of The World Unite". Na płycie: The Smiths. Louder Than Bombs. Sire Records, 1987.

Morrissey. “Asleep”. Na płycie: The Smiths. The World Won't Listen. Rough Trade Records, 1987.

Morrissey. "Half A Person". Na płycie: The Smiths. The World Won't Listen. Rough Trade Records, 1987.

Morrissey. "Everyday Is Like Sunday". Na płycie: Morrissey. Viva Hate. HMV Records, 1988.

Morrissey. "I Am Hated For Loving". Na płycie: Morrissey. Vauxhall And I. Sire Records, 1994.

Morrissey. "Irish Blood, English Heart". Na płycie: Morrissey. You Are The Quarry. Attack Records, 2004.

Morrissey. "I'll Never Be Anybody's Hero Now". Na płycie: Morrissey. Ringleader Of The Tormentors. Attack Records, 2006. 


\begin{abstract}
Albums
Morrissey. Viva Hate. HMV Records, 1988.

Morrissey. Vauxhall And I. Sire Records, 1994.

Morrissey. You Are The Quarry. Attack Records, 2004.

Morrissey. Ringleader Of The Tormentors. Attack Records, 2006.

The Smiths. The Smiths. Rough Trade Records, 1984.

The Smiths. Hatful Of Hollow. Rough Trade Records, 1984.

The Smiths. Meat is Murder. Rough Trade Records, 1985.

The Smiths. The Queen is Dead. Rough Trade Records, 1986.

The Smiths. Louder Than Bombs. Sire Records, 1987.

The Smiths. The World Won't Listen. Rough Trade Records, 1987.
\end{abstract}

